secular, and intolerant of groups that oppose their political agendas. Their Religious Liberty and Education: A rhetoric often hides old prejudices Case Study of Yeshivas vs. New York, in new wrappings, such as unionism eds., Jason Bedrick, Jay P. Greene, or support for Palestine. A recent Matthew H. Lee, Rowman \& Littlefield, example occurred in an April 1, 2021 2020, pp. 145, \$30.00 hardcover.

\title{
God and School in New York
}

\section{Michael Astrue}

Our Founding Fathers dreamed that the First Amendment's guarantees of religious freedom would eliminate serious tensions between our government and our religious citizens. Though religious freedom is greater in the United States than in more self-consciously secular European democracies, regrettably, our Founders' dream never became a reality. The expansion of government in recent decades has taken us even further away from their dream.

Our educational establishmentan alliance between the state education administrators and leaders of teachers' unions-has become increasingly left-wing, militantly Jewish Telegraphic Agency interview with Randi Weingarten, president of the American Federation of Teachers, who dismissed the views of American Jews on education because they "are now part of the ownership class."

The essays in Religious Liberty and Education: A Case Study of Yeshivas vs. New York explore this fault line in American education by documenting and analyzing the State of New York's persistent efforts to close down the state's orthodox Jewish schools, the yeshivas, or to make them abandon much of their curricula in favor of the template required for public schools. The matter has become heated in New York as the result of a 2018 decision by the New York State Education Department (NYSED) to issue "guidance" imposing strict time and subject standards on private schools, including the mandate to teach twelve secular subjects for at least 17.5 hours per week. Later proposed as regulations by the state Board of Regents,

Michael Astrue is a former biotechnology CEO who served in senior roles in the administrations of Presidents Ronald Reagan, George H.W. Bush, George W. Bush, and Barack Obama, including Associate Counsel to the President, General Counsel of the United States Department of Health and Human Services, and Commissioner of Social Security. He has also published ten books of original and translated poetry under the pseudonym A.M. Juster. His most recent book is Wonder and Wrath (Paul Dry Books, 2020) and his translation of Petrarch's Canzoniere will be released in 2023. 
the enforcement regime consisted of public school district boards making determinations as to whether the private schools within their boundaries were in compliance, giving the districts control over the existence of their direct competitors. An outcry from stakeholders ensued, resulting in lawsuits and the withdrawal of the regulations for a period of public comment. The dispute is ongoing.

The book begins with an overview by Kevin Vallier that does an outstanding job of laying out the history of these disputes, although his essay falters at the end with a brief conclusion that makes strong normative statements untethered to its wealth of information. The next essay, by Ashley Berner, starts to provide an analytical context for understanding the issues that the subsequent authors explore in detail. What emerges in the subsequent essays is an exercise in overreach as the New York Department of Education adopts an Orwellian reading of the state's "substantial equivalence" statute in order to punish even academically outstanding yeshivas.

The New York statute, passed in 1894, and similar statutes around the country seem to intend for the state to stay out of religious education unless there is a serious question as to whether a religious school has failed to provide an education that is "substantially equivalent" to a public school education. Legislators were well aware that the pedagogies and curricula of religious schools would be very different from those in the public schools, and there is no evidence that they intended for state officials to tell religious educators how to run their schools. It also suggests that state regulators should not be looking at process, but at objective outcomes for accomplishment in core subjectssuch as English and mathematics-to ensure that students will be able to function as productive citizens.

Despite the perfectly reasonable and constitutional intentions of the New York legislators, the state has continued to interpret the law as mandating close equivalence in process. As Aaron Saiger's essay explains, the state has tried to dictate how much time (or "Carnegie units" in educational jargon) must be spent on each subject and what courses religious schools must include beyond core subjects, such as physical education. In other words, state regulators expect Jewish parents to pay a significant amount of money for an education that is a very close copy of the education being offered for free by the public schools-a requirement that would crowd out the time required for comprehensive religious study and, in 
effect, would eliminate the yeshivas' very reasons for existence.

British administrators pushed New York's loose logic even further. Charles L. Glenn's essay explains how the British Office for Standards in Education ("Offsted") accused Orthodox Jewish schools of violating "British values." In 2013 Offsted highly praised one yeshiva for girls aged three to ten for the quality of its education, but four years later it threatened that same yeshiva with closure because it was not teaching LGBT issues in the manner demanded by the agency, a position withdrawn after public outcry. Offsted inspectors at another yeshiva, one for high school girls, even asked the students such questions as: "Do you have a boyfriend?"; "What do you know about men being married to each other?" and "What do you think about Facebook?"

In 2019 the New York State Department of Education began rulemaking to interpret "substantial equivalence" in ways that would strengthen the hands of its enforcement arm. Despite almost 150,000 written objections, the Department pushed ahead and quickly faced three statutory and constitutional challenges, which are still pending.

The Supreme Court's 1972 decision in Wisconsin $v$. Yoder would seem to be promising for the yeshivas, since the Court ruled that the Amish need not offer a high school education at all. Aaron Saiger, though, points out the inconsistency in the majority opinion. Praising the self-reliance and good conduct of the Amish seems to suggest an unwritten standard for "good" religions, and thus should run afoul of the neutrality toward religion that the First Amendment intended. Saiger rightly suggests that the current Supreme Court would be likely to revisit Yoder if provided the opportunity.

Yoder is not the only problem at the Supreme Court for the yeshivas. In their essay, Howard Slugh and Devorah Goldman argue that Justice Scalia's 1990 opinion in Employment Division v. Smith makes the prospects for a constitutional victory more challenging for the yeshivas. In Smith two Native Americans were fired from their jobs as drug counselors because they had consumed peyote. They argued that the First Amendment protected their peyote consumption because it was part of their religious rituals, but lost because the Court reasoned that facially neutral statutes can prohibit religious conduct otherwise protected by the free exercise clause of the First Amendment.

The last group of essays puts the New York yeshiva controversy into 
a broader context. Similar state and church issues arise with Catholic schools, fundamentalist Christian schools, Muslim education, and home schooling. Jibran Khan's “Between Tradition and Regulation: What Can Muslim Education Offer the West?" was particularly impressive, providing a thoughtful case for traditional Muslim education.

Religious Liberty and Education does not come to neat conclusions, but that is to be expected. The New York controversy is still ongoing and there will be continued controversy in many states until there is definitive Supreme Court guidance. In the meantime, this brief collection achieves its goal of provoking thought on an important topic with facts and reasoned analysis, not the bombast that drives so many of our political debates. 